\title{
Knowledge and Practice of Family Planning among Female Basic School Teachers in the City of Accra, Ghana
}

\author{
Evelyn Akorfa Hodogbe ${ }^{1} \&$ Samuel Kofi Badu-Nyarko ${ }^{1}$ \\ ${ }^{1}$ Department of Adult Education and Human Resource Studies, School of Continuing and Distance Education, \\ University of Ghana, Legon, Ghana. \\ Correspondence: Samuel Kofi Badu-Nyarko, School of Continuing and Distance Education, University of Ghana, \\ Legon, Ghana.
}

Received: September 29, 2014

Accepted: October 21, $2014 \quad$ Available online: February 12, 2015

doi:10.11114/ijsss.v3i2.675

URL: http://dx.doi.org/10.11114/ijsss.v3i2.675

\begin{abstract}
Family planning has been practiced in Ghana since time immemorial but modern practices were adopted in 1969 when the Ghana government launched the program. Since then efforts had been made to publicize and establish family planning clinics across the country aimed at assisting couples to space births, prevent unwanted pregnancies, promote and highlight the acceptability and adoption of contraceptives as well as help infertile families. However, studies on them in relation to the working class have been limited. This study tended to find out the gap between knowledge and practice among female basic school teachers in a selected community in an urban setting in Accra. The study found out that knowledge and awareness about family planning is associated with the practice of family planning $(\mathrm{r}=0.747: \mathrm{p}<$ 0.05). It further showed that $77.6 \%$ were aware of family planning of which $71.3 \%$ are practicing one method or the other. Knowledge also correlates with the likeness of family planning among the female teachers $(r=0.712 ; \mathrm{p}<0.05)$.

It concluded that the level of knowledge and practice of family planning was high among the teachers and that the gap between knowledge and practice was insignificant. However, some respondents still mistake family planning for contraception.

It recommended that education on family planning must not be limited to only women and female teachers but to their spouses as well.
\end{abstract}

Keywords: Family planning, population. Basic school, contraceptives, female teachers

\section{Introduction}

It is an undisputable fact that the population the world over is rapidly increasing at an alarming rate. The world population over the years has risen from 2.5 billion in 1950 to 6.5 billion in 2008. Currently, Africa alone accounted for 967 million population, Asia 4,052 million, Oceania 35 million, America 915 million, and Europe 736 million (World Population Data Sheet, 2006, 2007, 2008) As such, in 1974, after much debate in Bucharest, family planning was accepted as human right of individuals and couples (article 14 (f) of World Population Action). This was revised in 1984 at an international conference on population held in Mexico City, and in 1994 at United Nation International Conference on Population and Development (I.C.P.D.) in Cairo Egypt, where program of action was adopted. As a result, many countries, including Africa have made effort to reduce fertility rate through family planning. As such , the world 's total fertility has reduced from 6 children per woman in 1960s to 3.8 children in 1998, 2.9 in 2000, 2.8 in 2002 to 2.7 children in 2006 and in 2008 it was 2.6 children per woman (World Population Data Sheet 2001, 2002, 2006 and 2008).

Family planning, until recently has been a sensitive subject in black Africa. Now, many African leaders accept family planning as an important health and fertility control measure. Whereas, the developed world has made significant strides in the reduction of fertility rate through family planning, same cannot be said about Sub- Saharan Africa, West Africa and Ghana in particular. The TFR of West Africa in 2000 was 5.9 children per woman and 5.7 children in 2008 (World Population Data Sheet, 2000, 2006 and 2008).

For many years, donors and governments focus attention on family planning in West Africa to improve maternal and child health to enhance economic development. Nonetheless, experts agree that Sub- Saharan Africa is undergoing a 
transition to fewer births per woman. As such, the practice of family planning has increased slightly; though, it remains relatively low. Early age at marriage, the social desirability for many children and limited access to regular education are some of the factors that keep fertility from decreasing more rapidly (Family Planning in West Africa- Population Reference Bureau, 1999 and 2007). As the use of family planning methods remains low, the average number of births per woman in the region (West Africa) is exceptionally high at 5.7 children per woman in 2008 (Oppong 1989; Nabila 1991). Moreover, considering the young age structure of West Africa, the number of women of reproductive age is expected to increase population growth and challenges to meet the different needs of these people (Nabila 1991; Adansi-Pipim et al., 1989). The combination of high fertility and a growing number of women of reproductive age sets the stage for continued rapid population growth.

A study conducted by Oni (1985) in Ilorin, Nigeria revealed that 60 percent of non-literate women and 98 percent of women of secondary education had knowledge on family planning. Yet only one percent of the non-literate and 22 percent of highly educated married women practice family planning methods. This is similar to Ujah (1991). In in another study by Oheneba-Sakyi and Takyi (1997) found out that there is a positive relationship between family planning and level of education. Similarly, Tawiah (1997) found 8.5 percent of married women with no formal education who are working practice family planning compared to 16.8 percent with middle school education and 28.7 percent with higher level of education. Thus, the ability to source for information might have accounted for this trend. In Napal for instance, some women had difficulty using family planning products or devices because their relatives or female friends were not using them (Pirow, 1997; Ehrlich \& Ehrlich 1987).

In sub-Saharan Africa, religious doctrines are interpreted to eatly fit into the general pro-natalist value system of the people. Aryee (1989) and Danquah-Mortey (1988) contend that the African's religious conception of the universe makes religion a very powerful motivator of fertility behavior. Such had been the case of India among the Muslim women who had lower use of family planning services than Hindu women and women from other religious groups (Bongaarts and Bruce 1995; Marge 2006). According to Caldwell and Caldwell (1990 \& 1992) traditional African religious values have sustained high fertility by acting directly to equate fertility with virtue and spiritual approval. Many of such people believe that children are from God (Assimeng 1998).

At the time of Ghana's independence in 1957, its population was barely 6 million. This increased to $6,726,815$ million in 1960 when the post-independence census was taken and to 8,559,313 in 1970. In 1984, according to Ghana national population policy 1994 , the population was $12,296,081$ million, which means Ghana's population almost doubled within the 24 year period between 1960 and 1984. In 1993, the population was 16 million and during the 2000 census, the population increased to about 20 million as predicted. Currently, Ghana's population is about 23.9 million according to the world's population data sheet 2010, and it was projected that by mid- 2025, it is likely to reach 33.7 million and by mid-2050, 48.8 million. This shows that the population of Ghana has tripled since 1957 (Ghana National Population Policy, 1994; Ghana Statistical Service, 2000; World Population Data Sheet, 2008).

It is against this backdrop that in 1966 family planning was introduced into the country and in 1969, Ghana adopted an explicit and comprehensive population policy entitled "Population Planning for National Progress and Prosperity: Ghana Population Policy" (Badu-Nyarko 1992). This document defines government's policy on population and affirmed their commitment to adopt and implement appropriate strategies and programmes to manage population in order to accelerate the pace of economic modernization to improve quality of life of Ghanaians (Ghana National Population policy, 1994). The objective of the policy was to reduce the population growth of 2.4 percent per annum at the time by about a third, by the year 2000 through systematic lowering of fertility levels. Contrary to these expectations, the growth rate has remained persistently high. However, there was a noticeable but gradual decline in total fertility rate from 6.7 children per woman in 1980, to 6.4 children in 1988, to 5.5 children per woman in 1993.Then in 2007, it was 4.4 children and currently, it is 4.3 children per woman. (Ghana Statistical Service, 1994, and Population Data Sheet, 2007 and 2008).This is still high compared to two children per woman for developed countries.

According to Ghana statistical service, 1994, low practice of modern family planning among couples in stable sexual union and the sexually active is a factor contributing to persistent high fertility, coupled with early marriages. Not only that, but also, slow attitudinal change towards it and unwillingness to practice the available methods. The low practice of family planning cannot be said to be the result of lack of knowledge or low level of education as pointed out by GDHS, 2008. The revised population policy of Ghana 1994 expects the current population growth of 3.0 percent to reduce to 1.5 percent by year 2020. It recognizes that such lowering of fertility rate at the time when traditional methods of birth postponement, spacing and abstinence are on the decline, it will require an increase in Contraceptive Prevalence Rate (CPR) to 28 percent by 2010 and to 50 percent by 2020 (National Population Policy, 1994).

Besides, a pregnant woman is faced with numerous challenges as a wife, mother and a career woman (Baffour, 1980; Bessenger \& Bertrand 2001). In Osu-Klottey, the study area, the situation is not different. During pregnancy, many 
women suffer from pregnancy related diseases and other changes which makes them incapable of performing their usual duties effectively, such as pregnant female teachers. She may be absent from school often, as a result, her standard of work may also reduce. Not only that, but she will have to take maternity leave when she is due - six weeks during her last months and the rest six weeks after delivery by Ghana Education Service (G.E.S.) regulations (Hodogbe, 2010). This makes it difficult for her to exclusively breastfeed the baby for the approved six months stipulated by Ghana Health Service. Besides, she is also faced with transfer to a distant school, where she has to commute back and forth, taking two or three vehicles before getting to work in the cities, as you are replaced immediately you take maternity leave. As a result, some expectant mothers are refusing to take the leave and stay on and deliver, while others take other teachers to assist and pay them until they resume work Hodogbe 2010).

There are several consequences of not planning a family. Too many children, too close and too early to a family, may affect the health of the woman, the children and the entire family; medically (physically), mentally and financially. Medically, the woman's health may be endangered as well as children. Financially, they would have to work extra hard to be able to take good care of the family and if they are not financially sound, the education, health; the entire wellbeing and future of the family may suffer (Bachrach 1984; Ayad et al. 1994; Ashford \& Makinson 1999; Blanc \& Grey, 2000; Blanc \& Way, 1998).

However, some people may not find it necessary to plan their family, there are many benefits of family planning to the individuals, couples, professionals such as teachers, communities as well as the nation. When a family is consciously planned, its entire present and future becomes well organized, secured, bright, less stressful and a happy one (Chandarani \& Breton 2001; Twum-Baah 1998).

As such, it is the contention of the authors that the persistent wide gap between knowledge and practice of family planning should be redressed. It is in this regard that this study seeks to find out whether the knowledge of family planning the people have acquired are being put into practice by female teachers of basic schools in Osu-Klottey Sub-Metropolitan area.

The area of study, Osu-Klottey, which is a sub-metropolitan of Accra metropolitan area, has its fair share of rapid population growth, which is being influenced by unplanned pregnancies, inadequate spacing of children and high demand for children in marriage, coupled with low practice of modern family planning. It has been widely recognized that family planning is the only intervention available to human beings for now to reduce fertility, space children and control the size of their families.

When family planning program was established in 1969, greater emphasis was placed on the role of the female. Extensive education was carried out and according to Ghana Demographic and Health survey (GDHS) 2008, knowledge of family planning is very high and almost universal in Ghana. They stated that about 98 percent of all women and 99 percent of all men have the knowledge and know at least a method of family planning. (Population Impact Project, 1994; GDHS, 2008).

In view of this, high fertility rate among the female teachers of Osu-Klottey basic schools cannot be said to be a result of lack of knowledge. Therefore, the question is do female teachers in Osu-Klottey basic schools, practice the knowledge they have acquired in family planning?

\subsection{Objectives of the Study}

The study seeks to achieve the following objectives:

a) To find out their level of knowledge of family planning.

b) To find out their attitudes and behaviors towards practicing the knowledge.

c) To find out whether their attitude and behaviors have been influenced by the knowledge.

d) To find out if there is the need for further educational intervention to bridge the gap between their knowledge and practice.

\section{Research Methodology}

In this study, survey research was used, as this was deemed most appropriate for this study. This was because of certain characteristics associated with the design. According to Gay (1987), a survey is an area of research that utilizes several basic procedures to obtain information from people in order to determine the status of that population. It measures many variables, can also test multiple hypotheses and determines specific characteristics of a group. Babbie (1990) also recommends the survey approach for generalizing from a sample to a population so that inferences can be made about some characteristics, attributes or behavior of the population. The above characteristics, however, point to the fact that survey design could be used to gather data with the view of finding out the gap between knowledge and practice of family planning and also generalize from a sample to a population of all female teachers of basic schools in Osu-Klottey 
Sub-Metro.

\subsection{Study Area}

Osu-Klottey is one of the sub-metropolises in Greater Accra Region. It has a population of about 96,634 according to 2000 population and housing census. Osu which is the capital of Osu-Klottey sub-metro, is also located in central Accra at the eastern part of Accra. It has a population of 44027 out of which 21168 are males and 22,859 are females (population and Housing Census, 2000). Osu, being a cosmopolitan town, hosts people from all walks of life. In spite of many schools located there, education is not a priority for the people.

\subsection{Population}

The target population for the study was female teachers of basic schools in Osu-Klottey Sub-Metropolitan area of Accra. The study covers only classroom teachers. They were selected from first cycle schools, which include kindergarten, primary and junior high schools made up of one hundred and seventy-six (176) female teachers.

\subsection{Sampling Procedures}

A sample size of one hundred and forty-one (141) respondents, which is 80 percent of the total population, was selected out of one hundred and seventy-six (176) subjects. Simple random sampling was used in their selection. This sampling method was used because it was deemed more appropriate for this study in order to give every member in the population an equal chance of being selected to eliminate biases. A sampling frame (the list of all female teachers in the circuit) was obtained from the circuit supervisor's office which was used for the selection process.

\subsection{Instruments of Data Collection}

The questionnaire comprises twenty-five (25) questions, which were developed based on the objectives of the study, and the literature reviewed. There were thirteen (13) close-ended questions of Likert and Semantic Differential scale. This is intended to bring out their personal details, their level of knowledge, their attitudes and behaviors towards practicing the knowledge, influence of their knowledge on practice of family planning, as well as if there is the need for further intervention to bridge any gap. The questionnaires were distributed to the selected female teachers and the heads of the selected schools assisted in the retrieval of the completed questionnaires.

\section{Results}

The study has four main objectives to guide its analysis and these are (1) to find out the level of knowledge of family planning on practice, (2) to establish whether attitudes reflect behavior and practice, (3) to see if attitudes have been influenced by the knowledge and (4) examine if there is the need for further educational intervention to bridge the gap between knowledge and practice.

To statistically test these objectives, they have to be changed to more testable language; four hypotheses have been formulated as highlighted in the analysis with the Pearson Moment of Correlation Co-efficiency, which establishes the relationship between and among variables.

\subsection{Knowledge and Practice of Family Planning}

The first assumption tries to establish the association between knowledge and practice of family planning. The correlation matrix and the Standard Deviation tables explain the results.

Table 1. Correlations Matrix of Study Variables

\begin{tabular}{llll}
\hline Variables & Correlations & $\begin{array}{l}\text { Knowledge/Awareness } \\
\text { of Family Planning }\end{array}$ & $\begin{array}{l}\text { Extent of Practise of family } \\
\text { Planning }\end{array}$ \\
\hline Knowledge/Aware-ness about & Pearson $\mathrm{r}$ & 1 & $.747^{* *}$ \\
Family Planning & Sig. (2-tailed) & & .000 \\
& $\mathrm{~N}$ & 141 & 141 \\
Extent of Practice of & Pearson $\mathrm{r}$ & $.747^{* *}$ & 1 \\
Family Planning. & Sig. (2-tailed) & .000 & \\
& $\mathrm{~N}$ & 141 & 141 \\
\hline
\end{tabular}

**. Correlation is significant at 0.01 level (2-tailed).

The results indicate as portrayed by the table that, knowledge/awareness about family planning is associated with extent of practice of family planning. 
Table 2. Mean and Standard Deviation Classified by Knowledge and Practice of Family Planning among the Respondents

\begin{tabular}{lccccc}
\hline Variables & Mean & $\begin{array}{c}\text { Standard } \\
\text { Deviation }\end{array}$ & df & R & P \\
\hline $\begin{array}{l}\text { Knowledge/Awareness } \\
\text { about Family Planning }\end{array}$ & 3.9220 & 1.39423 & 139 & 0.747 & .000 \\
$\begin{array}{l}\text { Extent of Practice of } \\
\text { Family Planning. }\end{array}$ & 6.1915 & 1.75627 & & & \\
\hline
\end{tabular}

From the table, knowledge/awareness about family planning score $(\underline{M}=3.9220, \underline{S D}=1.39423)$ was found to be significantly different from the Extent of Practice of Family Planning score $(\underline{M}=6.1915, \underline{S D}=1.75627) \mathrm{r}$ (139) $=.747$, $\mathrm{p}<.000$. This is far below the accepted $.05 \%$. This implies that respondents with higher awareness also had higher score on the Extent of Practice of Family Planning than the respondents who had lower score on the knowledge. Thus, the correlation results have indicated that the higher the level of Knowledge/Awareness on Family Planning, the higher the Extent of Practice. This confirms the hypothesis that "better awareness and knowledge about family planning will lead to better practice of it".

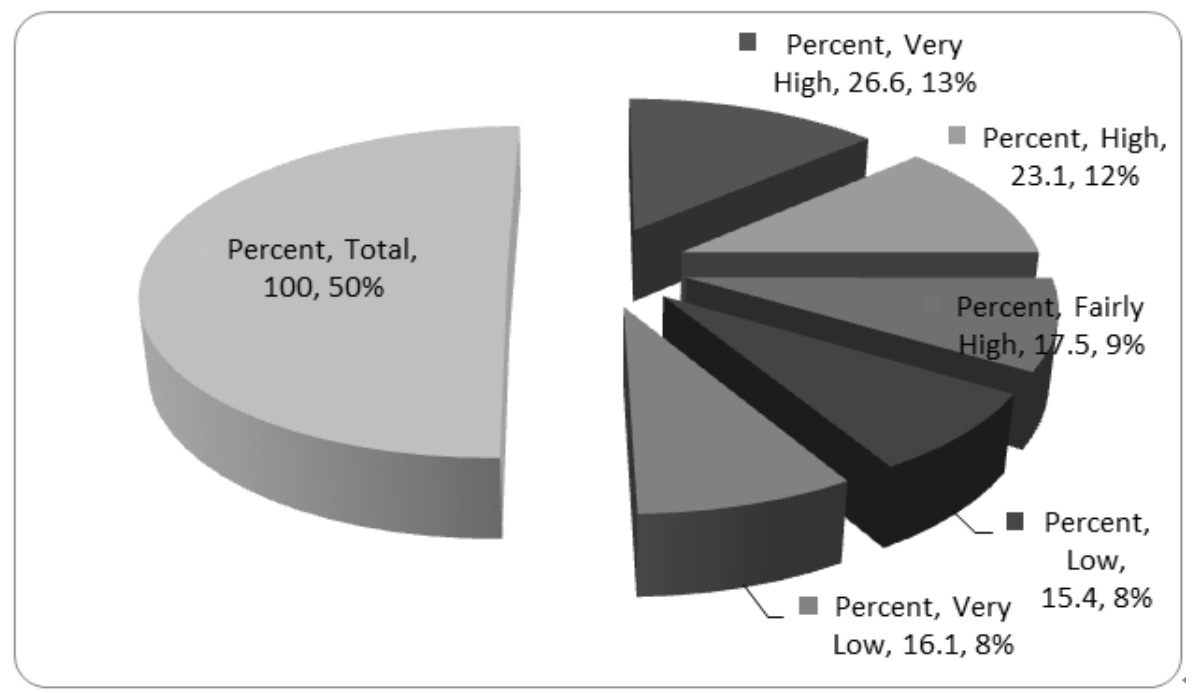

Figure 1. The Extent of Respondents' awareness of Family Planning

The descriptive statistics portrays that a lot more of the respondents $77.6 \%$ as against $21.0 \%$ are aware of family planning. From all indications, their extent of awareness is very high of $26.6 \%$; high extent is $23.1 \%$ as highlighted on figure 1 above.

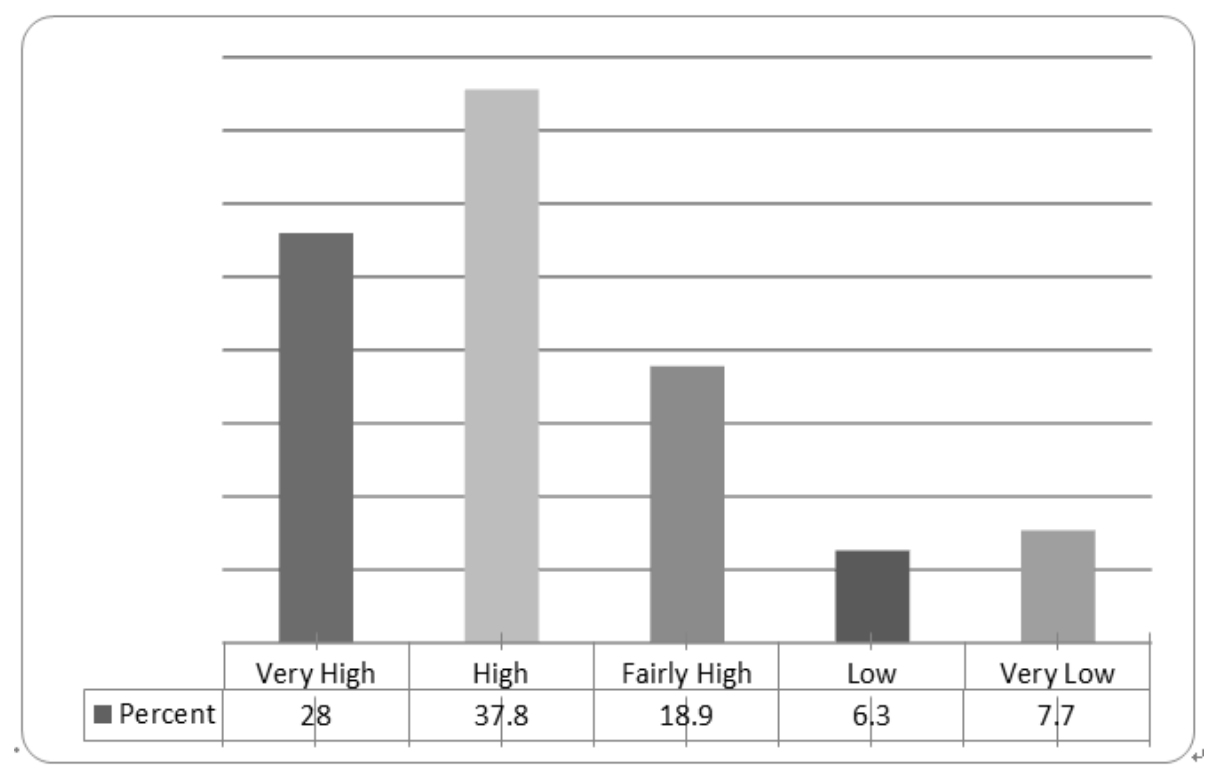

Figure 2. The Extent to which Respondents have been practicing Family Planning 
In almost all the patterns, those who practice the family planning are $71.3 \%$ as against $27.3 \%$. For the extent of practice, $28.0 \%$ is very high, while $37.8 \%$ practice at a high extent, $18.9 \%$ responded as high with very few respondents practising at low and very low rates thus, $6.3 \%$ and $7.7 \%$ respectively.

\subsection{Attitudes and Behaviors towards Family Planning}

The figure below indicates that Knowledge correlates with Likeness for Family Planning among the Respondents.

Table 3. Correlations Matrix of Study Variables

\begin{tabular}{lllll}
\hline Variables & Correlation & $\begin{array}{l}\text { Knowledge / } \\
\text { Awareness }\end{array}$ & $\begin{array}{l}\text { Likeness of } \\
\text { Family Planning. }\end{array}$ & $\begin{array}{r}\text { Extent of } \\
\text { likeness }\end{array}$ \\
\hline Knowledge/ & Pearson Correlation & 1 & $.712^{* *}$ & $.807^{* *}$ \\
Awareness & Sig. (2-tailed) & & .000 & .000 \\
& $\mathrm{~N}$ & 141 & 141 & 141 \\
Likeness for & Pearson $\mathrm{r}$ & $.712^{* *}$ & 1 & $.689^{* *}$ \\
Family Planning & Sig. (2-tailed) & .000 & & .000 \\
& $\mathrm{~N}$ & 141 & 141 & 141 \\
Extent of likeness & Pearson r & $.807^{* *}$ & $.689^{* *}$ & 1 \\
& Sig. (2-tailed) & .000 & .000 & \\
& $\mathrm{~N}$ & 141 & 141 & 141 \\
\hline
\end{tabular}

**. Correlation is significant at the 0.01 level (2-tailed).

Table 4. Mean and Standard Deviation Classified by Knowledge and Likeness of Family Planning among the Respondents

\begin{tabular}{llllll}
\hline Variables & Mean & Std. Deviation & df & $R$ & $P$ \\
\hline Knowledge/Awareness about Family & 3.9220 & 1.39423 & & & \\
Planning & & & 139 & .712 & .000 \\
Likeness for Family Planning & 1.1206 & .32678 & & &
\end{tabular}

According to the tables, knowledge/awareness about family planning score $(\underline{\mathrm{M}}=3.9220, \underline{\mathrm{SD}}=1.39423)$ was found to be significantly different from the likeness for family planning score $(\underline{M}=1.1206, \underline{S D}=.32678) r_{(139)}=.712, p<.000$. This is far below the accepted level of $.05 \%$. This implies that respondents with higher awareness also had higher score on likeness for family planning than the participants who had lower score on the knowledge had on likeness for it. Thus, the correlation results have indicated that the higher the level of knowledge/awareness about family planning, the higher is the likeness for it. This confirms the hypothesis that "better awareness and knowledge about family planning will lead to better Likeness for it".

Table 5. Mean and Standard Deviation Classified by Knowledge and Extent of likeness for or attitude towards Family Planning among the Respondents

\begin{tabular}{llllll}
\hline Variables & Mean & Std. Deviation & df & $R$ & $P$ \\
\hline $\begin{array}{l}\text { Knowledge/Awareness about } \\
\text { Family Planning }\end{array}$ & 3.9220 & 1.39423 & & & \\
Extent of attitude & 2.3901 & 1.40800 & & & \\
\hline
\end{tabular}

The study has revealed that, Knowledge/Awareness about Family Planning score ( $\underline{\mathrm{M}}=3.9220, \underline{\mathrm{SD}}=1.39423)$ was found to be significantly different from the Extent of attitude towards Family Planning score $(\underline{M}=2.3901, \underline{S D}=1.40800) r_{(139)}$ $=.807, \mathrm{p}<.000$. This is far below or well within the accepted $.05 \%$. This implies that respondents with higher awareness also had higher score on the Extent of likeness/attitude towards Family Planning than the respondents who had lower score on the knowledge had on the extent of likeness for it. Thus, the correlation results have indicated that the higher the level of Knowledge/Awareness about Family Planning, the higher is the Extent of likeness for it. This supports the hypothesis that "better awareness and knowledge about family planning will lead to better attitude towards it". 
Table 6. Correlations Matrix of Study Variables

\begin{tabular}{llll}
\hline Variables & Correlation & $\begin{array}{c}\text { Attitude towards } \\
\text { Family Planning }\end{array}$ & $\begin{array}{c}\text { Extent of } \\
\text { Practice }\end{array}$ \\
\hline Attitude towards & Pearson $\mathrm{r}$ & .712 & .689 \\
Family Planning & Sig. (2-tailed) & .000 & .000 \\
& $\mathrm{~N}$ & 141 & 141 \\
Extent of Practice & Pearson $\mathrm{r}$ & .689 & 1 \\
& Sig. (2-tailed) & .000 & \\
& $\mathrm{~N}$ & 141 & 141 \\
\hline
\end{tabular}

** .Correlation is significant at the 0.01 level (2-tailed).

**.Correlation is significant at the 0.01 level (2-tailed).

Note: Attitude and practice because all the questions measuring attitude were put together and so was all the items measuring practice.

Table 7. Mean and Standard Deviation Classified by Knowledge and Extent of likeness for or attitude towards Family Planning among the Respondents

\begin{tabular}{llllll}
\hline Variables & Mean & Std. Deviation & df & $R$ & $P$ \\
\hline Attitude Towards & 3.9220 & 1.39423 & & & \\
$\begin{array}{c}\text { Family Planning } \\
\text { Extent of Practice of }\end{array}$ & & & 139 & .807 & .000 \\
Family Planning. & 1.1206 & .32678 & & & \\
\hline
\end{tabular}

From the tables, Attitude towards Family Planning score $(\mathrm{M}=3.9220, \underline{\mathrm{S}}=1.39423)$ was found to be significantly different from the Extent of Practice of Family Planning score $(\underline{\mathrm{M}}=1.1206, \underline{\mathrm{SD}}=.32678) \mathrm{r}_{(139)}=.807, \mathrm{p}>.000$. This significant level is far below or well within the accepted $.05 \%$. This implies that respondents with higher score on Attitude towards Family Planning also had higher score on the Extent of Practice of Family Planning than the participants who had lower score on the Attitude towards Family Planning had on the Extent of Practice of Family Planning than their counterparts. In other words, there is correlation between attitude and practice of Family Planning; which supports the hypothesis that "better attitude/likeness towards family planning will result in high practice of it". 3.3 Further sensitization on knowledge and Practice

The correlation table suggests that there is the need to further sensitize the female teachers on the difference between the concept of family planning and contraceptives (including the various types, their usage and their side effects). This may likely lead to an increase in the practice of family planning. The tables also explain the kind of relationships between further expansion of knowledge and its effects on the knowledge and practice of family planning.

Table 8. Correlations Matrix of Study Variables

\begin{tabular}{|c|c|c|c|c|}
\hline Variables & Correlation & $\begin{array}{l}\text { Is there the need } \\
\text { for further } \\
\text { sensitization of } \\
\text { the people }\end{array}$ & $\begin{array}{c}\text { To what extent will } \\
\text { that lead to } \\
\text { awareness }\end{array}$ & $\begin{array}{c}\text { To what extent will } \\
\text { that lead to more } \\
\text { practice }\end{array}$ \\
\hline \multirow{3}{*}{$\begin{array}{l}\text { Is there the need for further } \\
\text { sensitization of the people }\end{array}$} & Pearson $r$ & 1 & $.319^{* *}$ & $.261^{* *}$ \\
\hline & Sig.(2-tailed) & & .000 & .002 \\
\hline & $\mathrm{N}$ & 141 & 141 & 141 \\
\hline \multirow{3}{*}{$\begin{array}{c}\text { To what } \\
\text { extent is your level of } \\
\text { awareness }\end{array}$} & Pearson $\mathrm{r}$ & $.319^{* *}$ & 1 & $.248^{* *}$ \\
\hline & Sig. (2-tailed) & .000 & & .003 \\
\hline & $\mathrm{N}$ & 141 & 141 & 141 \\
\hline \multirow{3}{*}{$\begin{array}{c}\text { To what extent will } \\
\text { that lead to } \\
\text { more practice }\end{array}$} & Pearson $r$ & $.261^{* *}$ & $.248^{* *}$ & 1 \\
\hline & Sig. (2-tailed) & .002 & .003 & \\
\hline & $\mathrm{N}$ & 141 & 141 & 141 \\
\hline
\end{tabular}

**. Correlation is significant at the 0.01 level (2-tailed). 
Table 9. Mean and Standard Deviation Classified by Knowledge and Extent of likeness for or attitude towards Family Planning among the Respondents

\begin{tabular}{llllll}
\hline Variables & Mean & Std. Deviation & df & $R$ & $P$ \\
\hline Need for further sensitization & 1.2624 & .44151 & & & \\
To what extent will that lead to awareness & 2.7092 & 1.43198 & 139 & .319 & .000 \\
\hline
\end{tabular}

Furthermore, the need for further sensitization on family planning score $(\underline{M}=1.2624, \underline{S D}=.44151)$ was found to be significantly different from the extent to which it will lead to awareness about family planning score $(\underline{\mathrm{M}}=2.7092$, $\underline{\mathrm{SD}}=1.43198) \mathrm{r}_{(139)}=.319, \mathrm{p}>.000$. This significant level is far below the accepted $.05 \%$. This implies that respondents with higher score on the need for further sensitization of the people about family planning did have higher score on the extent to which that will lead to expansion of awareness on family planning than those with lower score on lower further sensitization had on its impact on further awareness creation. This supports the hypothesis that further sensitization will lead to filling the information gap between awareness sensitization. In other words, there is a correlation between further sensitization and awareness creation considering some of the responses given by the respondents. For instance, they were asked whether they practice family planning, and some of the responses were "no, 1 abstain from sexual intercourse during my fertile periods" and others, "no, my husband does not like it so he rather withdraws during ejaculation to prevent pregnancy". These responses are clearly referring to rather some of the methods of contraception and not family planning per say.

Table 10. Mean and Standard Deviation Classified by Knowledge and Extent of likeness for or attitude towards Family Planning among the Respondents

\begin{tabular}{llllll}
\hline Variables & Mean & Std. Deviation & Df & $R$ & $P$ \\
\hline $\begin{array}{l}\text { Need for further } \\
\text { sensitization }\end{array}$ & 1.2624 & .44151 & & & \\
To what extent will that lead to more practices & 1.2766 & .44891 & & .261 & .002 \\
\hline
\end{tabular}

More so, the need for further sensitization about Family Planning score $(\underline{M}=1.2624, \underline{S D}=.4415)$ was found to be significantly different from the extent to which that will lead to more practices of family planning score $(\underline{M}=1.2766$, $\underline{\mathrm{SD}}=.44891) \mathrm{r}_{(139)}=.261, \mathrm{p}>.002$. This significant level is far above the accepted $.05 \%$. This implies that respondents with higher score on need for further sensitization about Family Planning did have higher score on the extent to which that will lead to more practises of family planning or the respondents who had lower score on the need for further sensitization about family planning did not have higher score on the extent to which that will lead to more practices of family planning than their counterparts.

\subsection{Effects of Some Demographic Factors on Knowledge and Practice of Family Planning}

Factors such as level of formal education, Religion, Marital Status and Numbers of children and how they are spaced are very important when studying family planning. It is very important because of their influences on the knowledge and practices. The result suggests that demographic, the selected education, religion and marital status do not affect the level of knowledge and practice, the number of children of the respondents and their spacing in the study. The fact is that there was no significant differences at all among them as highlighted on the series of tables except the level of education and the number of children the parents have. 
Table 11. The Relationships among Demographic Variables and Awareness and Practice of Family Planning

\begin{tabular}{llllll}
\hline Variable & Mean & Std. Deviation & $\mathrm{N}$ & $\mathrm{R}$ & $\mathrm{P}(\mathrm{Sig})$ \\
\hline Education & 3.6241 & .55471 & 141 & -.010 & .909 \\
Practice & 1.2766 & .44891 & 141 & & \\
Education & 3.6241 & .55471 & 141 & .009 & .919 \\
Awareness & 1.2128 & .41072 & 141 & & \\
Education & 3.6241 & .55471 & 141 & $.283^{* *}$ & .001 \\
No: of Children & 2.9389 & 1.28755 & 131 & & \\
Religion & 1.1522 & .41684 & 138 & .080 & .351 \\
Practice & 1.2766 & .44891 & 141 & & \\
Religion & 1.1522 & .41684 & 138 & -.018 & .837 \\
Awareness & 1.2128 & .41072 & 141 & & \\
Religion & 1.1522 & .41684 & 138 & .149 & .039 \\
No: of Children & 2.9389 & 1.28755 & 131 & & \\
Marital status & 2.0213 & 1.74220 & 141 & .029 & .733 \\
Practice & 1.2766 & .44891 & 141 & & \\
Marital status & 2.0213 & 1.74220 & 141 & .103 & .222 \\
Awareness & 1.2128 & .41072 & 141 & & \\
Marital status & 2.0213 & 1.74220 & 141 & .167 & .057 \\
No: of Children & 2.9389 & 1.28755 & 131 & & \\
\hline
\end{tabular}

One of the most striking finding of the study is the fact that the highly educated respondents rather had more number of children. Thus, there is a positive moderate correlation between higher education level and larger number of children born. This defeats the already known fact about highly educated women and their tendency to give birth to fewer children.

Table 12. Correlations Matrix of Study Variables

\begin{tabular}{llll}
\hline \multicolumn{1}{c}{ Variables } & \multicolumn{1}{c}{ Correlation } & Level of Education & $\begin{array}{c}\text { Number of children } \\
\text { respondents have }\end{array}$ \\
\hline Level of Education & Pearson Correlation & 1 & $.283^{* *}$ \\
& Sig. (2-tailed) & & .001 \\
& $\mathrm{~N}$ & 141 & 131 \\
Number of children the & Pearson Correlation & $.283^{* *}$ & 1 \\
respondents have & Sig. (2-tailed) & .001 & 131 \\
& $\mathrm{~N}$ & 131 & \\
\hline
\end{tabular}

Table 13. Mean and Standard Deviation Classified by Education Level and the number of children of the Respondents

\begin{tabular}{llllll}
\hline Variables & Mean & Std. Deviation & df & $R$ & $P$ \\
\hline Education Level & 3.6241 & .55471 & & & \\
Number of children & 2.9389 & 1.28755 & 139 & $.283^{* *}$ & .001
\end{tabular}

From the table, Education Level score $(\underline{\mathrm{M}}=3.6241, \underline{\mathrm{SD}}=.55471)$ was found to be significantly different from the Number of children score $(\underline{M}=2.9389, \underline{S D}=1.28755) \mathrm{r}_{(139)}=.283^{* *}, \mathrm{p}>.001$. This significant level is far below and within the accepted $.05 \%$. This implies that respondents with higher score on Education Level did have higher score on the number of children they have or the respondents who had lower score on education level did have lower score on the number of children they have than their counterparts. This does not support the hypothesis that highly educated women normally have fewer children. However, this is not one of the initial assumptions, the study has indicated this.

\section{Discussion and Conclusion}

The study established that among working class women particularly female teachers there exist a high level of knowledge and practice of family planning. This might be so due to their interaction with reading materials and regular contact with personnel of family planning issues (Awusabo-Asare 2001; Curtis \& Neitzel 1996). Added to these is the fact that many of the literature and media discussions were in the English language which is comfortable with the teachers. In terms of practice, these teachers are faced with specific maternity and other leaves within the year and so efforts are continuously made in other to satisfy the conditions of their employers by spacing births and limiting the number of children (Boateng. 1990 and Twum 2001 cited in Hodogbe 2010). Information dissemination is essential in order to fill in the gap of issues pertaining to the side effects and prospects of family planning to promote practice Hodogbe, 2010; Edwards 1996; Hatcher 1997 cited in Hodogbe 2010; Joesoef 1988).

The correlation between knowledge and practice was therefore high. Also, female basic school teachers attitude towards 
family planning was not based exclusively on husbands approval as found by Ezeh (1993). This shows the level to which educated elites and the working class seem to adopt innovations quicker. The study further confirms Rogers (1985) innovation theory that early adopters are basically highly educated of middle income status and urban based. Thus, the characteristics of the study population correspond to this assertion. For although few of the have deeper knowledge but not practicing may be due to personal reasons or religious factors but nothing else. The study established that the higher the level of knowledge and awareness about family planning, the higher the extent of likeness for it and practice. Thus, it could be indicated that the knowledge level on family planning of the teachers have actually influenced their practice positively.

\section{References}

Adansi-Pimpim, G., Kwafo, S. K., \& Gardiner, C. (1989). Family planning and maternal and child health: The experience in Ghana, Development in Family Policies and Programmes in Africa. Legon. Ghana. (RIPS), 319-350.

Ashford, L., \& Makinson, S. (1999). Reproductive health in policy and practice: Case studies from Brazil, India, Morocco and Uganda, Population Reference Bureau. Washington.

Awusabo-Asare, K. (2001). Factors influencing youth sexuality in Ghana, Studies in Family Planning. Ghana.

Assimeng, M. (1988). Social structure of Ghana; a study of persistence and change. Accra, Ghana Publishing Corporation.

Aryee, A. F. (1989). Socio-cultural policies and programmes for efficient family planning in Africa, Development in Family Planning and Programmes in Africa. Accra, Ghana.

Ayad, M. et al (1994). Sources of contraceptive methods, Demographic and Health Survey Comparative Studies, 11, 34-39.

Badu-Nyarko, S. K. (1992). An evaluation of the educational programmes of the Planned Parenthood Association of Ghana (PPAG) and its effect on the Tarkwa and Axim areas (Western Region). (Unpublished Master of Philosophy Thesis). University of Ghana, Legon. Ghana.

Bachrach, C. A. (1984). Contraceptive practices among American women 1973-1982, Family Perspectives, 19(6), 253. http://dx.doi.org/10.2307/2134914

Baffour. A. (1980). Social-culture factors that affect fertility of women in Nkoransa District. (Unpublished Theses) School of Medical Science, University of Science and Technology, Kumasi.

Bessinger, R. F., \& Bertrand, J. T. (2001). Monitoring quality of care in family planning programs. A comparasion of observations and client interviews. International Family Planning Perspectives, 27(2), 63-70. http://dx.doi.org/10.2307/2673816

Blanc A. K., \& Way, A. A. (1998). Sexual behaviour and contraceptive knowledge and use among adolescents in developing countries, Studies in Family Planning, 29(21), 100-120.

Blanc, A. K., \& Grey, S. (2000). National Population Council Secretariat. Calverton: Macro International.

Boateng, S. K. (1990). Koforidua junior secondary school teachers and the contraceptives. (unpublished project work). Department of Sociology, University of Ghana. Legon.

Bongaarts, J., \& Bruce, J. (1995). The causes of unmet needs for contraception and social content of services, Studies in Family Planning, 26(2), 57-75. http://dx.doi.org/10.2307/2137932

Chandani, Y., \& Breton, G. (2001). Contraceptive security, information flow, and local adaptions: Family planning in the Philippines and Morocco. Electronic Journal for Information Systems in Developing Countries, 5(3), 1-18. www.is.cityu.edu.hk/research/ejisdc/vol5/v5r3.pdf

Caldwell, J. C., \& Caldwell, P. (1990). High fertility in Sub-Saharan Africa, Scientific America, 26(2), 118-25. http://dx.doi.org/10.1038/scientificamerican0590-118

Caldwell J. C., \& Caldwell, P. (1992). Fertility decline in Africa: A new type of transition? Population and Development Review, 18(2), 211-241. http://dx.doi.org/10.2307/1973678

Curtis, S. L., \& Neitzel, C. (1996). Contraceptive knowledge, use and source in demographic and health survey. Comparative Studies, 19, 24-31.

Dankwa-Mortey, J. (1988). Contraceptive knowledge and use in Mpraeso, Kwahu District of Ghana. (Unpublished dissertation), University of Ghana. Legon. Ghana.

Ehrlich, P. R., \& Ehrlich, A. H. (1987). Population, Resources and Environment. San Francisco. Freeman.

Ezeh, A. C. (1993). The influence of spouses over each other's contraceptive attitude in Ghana, Studies in Family 
Planning, 24(23), 163. http://dx.doi.org/10.2307/2939231

Edwards, S. R. (1996). The role of men in contraceptive decision making current knowledge and future implications. Family Planning Perspectives, 26(2), 72.

Ghana Statistical Service (2008). Ghana Demographic and Health Survey. Accra, Ghana.

Ghana Statistical Service (2003). Ghana Demographic and Health Survey. Accra. Ghana

Ghana Statistical Service (1998). Ghana Demographic and Health Survey. Accra. Ghana

Hatcher, R. A. (1997). The essentials of contraceptive technology, John Hopkins Population Communication Programmes. Baltimore.

Hodogbe, E. A. (2010). The gap between knowledge and practice of family planning among female teachers of basic schools in Osu-Clottey sub-metropolitan area. (Unpublished Master of Arts Dissertation, University of Ghana, Legon. Ghana.

Joesoef, M. R., Baughman, A. L., \& Utomo, B. (1988). Husbands' approval of contraceptive use in Metropolitan Indonesia: Programme implications. Studies in Family Planning, 19(3), 162-168. http://dx.doi.org/10.2307/1966751

Lamptey, et al (1978). An evaluation of male contraceptive acceptance Rural Ghana, Studies in Family Planning.

Marge, B. (2006). Condoms, Yes! Abstinence, No" Reproductive Health Matters, 14(8), 6-16.

Nabila, J. S. (1991). Research monitoring and evaluation components of Ghana Population Policy: Future challenges, Sector Policy Unit. Accra. Ghana

National Population Council (1994). Government of Ghana National Population Policy. Accra. Advent Press.

National Research Council (1993). Population Dynamics Sub-Saharan Africa, Washington D.C. National Academy Press.

Oni, G. A. (1985). Effects of women's education on Post Partum practices and fertility in Urban Nigeria, Studies in Family Planning, 6, 97-108.

Oppong, C. (1989) Women: Role and gender issues in family planning in Africa. Development in Family Planning Policy Programmes in Africa. Accra. Ghana.

Oheneba-Sakyi, Y., \& Takyi, B. K. (1997). Effects of couples characteristics on contraceptive use in Sub-Saharan Africa. Journal of Biosocial Science, 2, 26-86.

Pitrow, P. T. et al (1977). Health communication, lessons from family planning reproductive health. New Jersey: Greenwood.

Population Reference Bureau. (2007). Population and Economic Development Data Sheet. Washington, DC. Population Reference Bureau (2008). World Population Highlights. Washington.

Rogers, M. E. (1995). Diffusion of innovation. ( $3^{\text {rd }}$ Ed.). New York: Allyn

Smith, E. R., \& Mackie, D. M. (1995). Social psychology. New York: Worth.

Tawiah, E. O. (1999). Male fertility, contraceptive use and fertility in Ghana. Third African Population Conference in the $21^{\text {st }}$ Century. Ghana.

Tawiah, E. O. (1997). Factors affecting contraceptive use in Ghana. Journal of Biosocial Science. 2, 120-160.

Twum-Baah, K. A. (1998). Family planning service delivery in Ghana, Ghana Statistical Service. Accra.

Twum, S. A. (2001). Knowledge, attitude and use of contraception in Awukugua, Eastern Region, (Unpublished Bachelor of Arts dissertation). University of Ghana. Legon. Ghana.

United State Agency for International Department (1984). Family Planning Methods and Practice in Africa. Atlanta, Georgia.

Ujah, I. A. (1991). Sexual activity and attitude towards contraception among women seeking termination of pregnancy in Zaria, Northern Nigeria, International Journal of Gynaecology and Obstetrics, 35(1). 78-100. http://dx.doi.org/10.1016/0020-7292(91)90067-F

United Nations (1991). World Population Prospects. The 1998 Revision, Analytical Report, Highlights. New York.

(cc) Br

This work is licensed under a Creative Commons Attribution 3.0 License. 